\title{
"Benchmarking of bank performance using the life cycle concept and the DEA approach"
}

\begin{tabular}{|c|c|}
\hline AUTHORS & $\begin{array}{l}\text { Volodymyr Ponomarenko } \\
\text { Oleh Kolodiziev (D http://orcid.org/0000-0002-6715-2901 } \\
\text { R http://www.researcherid.com/rid/C-6094-2018 } \\
\text { Iryna Chmutova (D http://orcid.org/0000-0001-7932-7652 }\end{array}$ \\
\hline ARTICLE INFO & $\begin{array}{l}\text { Volodymyr Ponomarenko, Oleh Kolodiziev and Iryna Chmutova (2017). } \\
\text { Benchmarking of bank performance using the life cycle concept and the DEA } \\
\text { approach. Banks and Bank Systems, 12(3), 74-86. } \\
\text { doi:10.21511/bbs.12(3).2017.06 }\end{array}$ \\
\hline DOI & http://dx.doi.org/10.21511/bbs.12(3).2017.06 \\
\hline RELEASED ON & Tuesday, 29 August 2017 \\
\hline RECEIVED ON & Monday, 05 June 2017 \\
\hline ACCEPTED ON & Thursday, 20 July 2017 \\
\hline LICENSE & $\begin{array}{l}(c) \text { EY } \\
\text { This work is licensed under a Creative Commons Attribution } 4.0 \text { International } \\
\text { License }\end{array}$ \\
\hline JOURNAL & "Banks and Bank Systems" \\
\hline ISSN PRINT & $1816-7403$ \\
\hline ISSN ONLINE & $1991-7074$ \\
\hline PUBLISHER & LLC "Consulting Publishing Company "Business Perspectives" \\
\hline FOUNDER & LLC "Consulting Publishing Company "Business Perspectives" \\
\hline
\end{tabular}

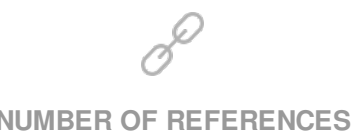

52

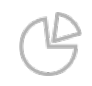

NUMBER OF FIGURES

1

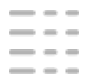

NUMBER OF TABLES

4

(C) The author(s) 2023. This publication is an open access article. 


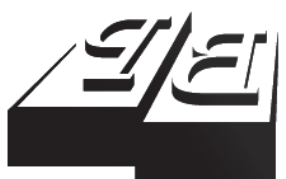

BUSINESS PERSPECTIVES

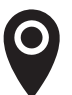

LLC "CPC "Business Perspectives" Hryhorii Skovoroda lane, 10, Sumy, 40022, Ukraine

www.businessperspectives.org

Received on: $5^{\text {th }}$ of June, 2017

Accepted on: $20^{\text {th }}$ of July, 2017

(C) Volodymyr Ponomarenko, Oleh Kolodiziev, Iryna Chmutova, 2017

Volodymyr Ponomarenko, Rector, Simon Kuznets Kharkiv National University of Economics, Ukraine.

Oleh Kolodiziev, Chief of Department of Banking, Simon Kuznets Kharkiv National University of Economics,

Ukraine.

Iryna Chmutova, Professor at Department of Banking, Simon Kuznets Kharkiv National University of Economics, Ukraine.
Volodymyr Ponomarenko (Ukraine), Oleh Kolodiziev (Ukraine), Iryna Chmutova (Ukraine)

\section{BENCHMARKING OF BANK PERFORMANCE USING THE LIFE CYCLE CONCEPT AND THE DEA APPROACH}

\begin{abstract}
Despite the widespread use of benchmarking as an effective tool for improving the efficiency of the bank's functioning, its implementation does not take into account the relation between comparable performance indicators, the choice of benchmark for comparison, deviations of indicators from target values with stages of the bank's life cycle, which cause differences in the intensity and characteristics of development of financial institutions. The procedure for identifying a reference bank for comparison is also insufficiently specified, which is important in terms of adapting its experience by the recipient bank due to the possible fundamental differences in their functioning. Therefore, the article has modified the technology of benchmarking of the bank's performance based on the life cycle concept and the DEA approach.
\end{abstract}

The research is based on the use of the DEA method to determine the most efficient bank as a reference bank in benchmarking comparison; canonical analysis - for the formation of a list of indicators of bank performance; cluster analysis - to substantiate the levels of deviations of the actual values of comparable indicators from the target ones.

The study envisages, firstly, the selection of indicators for benchmarking comparisons based on the identification of causal relationships between the indicators of subsystems "Finance", "Customers", "Business processes", "Personnel development" that arise at each stage of a bank's life cycle; secondly, the choice of a benchmark bank for comparison according to the maximum value of the performance indicator calculated through the DEA method for a set of banks that are at one and the same stage of their life cycle; thirdly, definition of the range of deviations (low, permissible, critical) of the actual values of comparable indicators of the effectiveness of management of finance, customer base, business processes and personnel of the bank from the target ones. A practical testing of the benchmarking technology was carried out on the example of Ukrainian banks, whose stage in 2016 was identified as "intense growth".

Keywords

bank, benchmarking, bank performance indicators, BSC, bank life cycle stage, DEA

\section{JEL Classification G21, C14, O12}

\section{INTRODUCTION}

It is important to ensure an effective operation of banks through continuous monitoring over the effectiveness of management of finances, customer base, business processes and personnel compared to those banks that are the leaders on the relevant market segment and through the implementation of those advanced methods and tools that have already proved to be effective.

A more active use of benchmarking by Ukrainian banks is also caused by the need to strengthen their adaptability and to ensure efficiency in response to negative trends in the banking sector: since 2008, its func- 
tioning is characterized by a decrease in efficiency (according to the results of 2016, the loss amounted to 159388 million UAH, the indicator of profitability of the assets and capital reached the lowest values in the last ten years: $-12.6 \%$ and $-116.74 \%$, respectively), deterioration in the quality of assets (in 2016, the volume of overdue debt amounted to $24.2 \%$ ), significant reduction in the number of operating banks (from 175 in the beginning of 2008 to 96 in the beginning of 2017) (National Bank of Ukraine, 2016).

The relevance of using benchmarking is confirmed by the surveys of more than 13000 respondents (company management) from more than 70 countries carried out by the consulting company Bain \& Company regarding the priority of using management tools (Rigby \& Bilodeau, 2015). According to the survey, benchmarking is in the top-10 management practices from 2000 to 2015, while in 2008, 2010 and 2011, it ranked first (in North America, it is now on the first position). In 2014, benchmarking was particularly popular among big companies. It was used by $44 \%$ of the surveyed companies compared to $40 \%$ in 2012 (in 2015, it was expected to reach 77\%). The level of management satisfaction with this technology is 3,8 points on a five-point scale. Experts of the Bain \& Company believe that benchmarking helps identify ways to improve performance, to focus on strategic opportunities, accelerate organizational learning through new ideas (Rigby \& Bilodeau, 2015).

The advantages of the use of benchmarking by Ukrainian banks include opportunities to compare the strengths and weaknesses of their activities with more successful banks, to realize the realistic achievable level of efficiency, to adjust the parameters of the bank's functioning in accordance with market requirements, to increase its competitiveness. In addition, benchmarking aims at identifying strategic reference points of banks for strengthening their positions, facilitating the transfer of new ideas and technologies.

Despite the fact that the world practice has a successful experience of using benchmarking, most Ukrainian banks do not fully utilize this technology and apply it without interrelation with the stages of life cycle that causes differences in strategic guidelines, developmental intensity, financial needs and goals of banks. The use of benchmarking without taking into account the stage of development of the bank may lead to inconsistency of the real results from its implementation and the expectations of the bank's management and other stakeholders, to low efficiency of financial decisions.

An important stage in benchmarking is the choice of reference points for comparison. This task is usually solved by compiling bank ratings. However, most rating methodologies generalize financial coefficients that can be multidirectional and not provide an opportunity to objectively measure the performance, while effectively functioning objects should be selected in benchmarking comparisons. Therefore, it is advisable to determine a reference bank based on the DEA method, in which, unlike other methods, efficiency is a key concept and is determined by comparing the related input and output parameters.

The purpose of the article is to develop a technology of banking benchmarking using the concept of life cycle and the DEA approach.

\section{LITERATURE REVIEW}

\subsection{The essence and stages of benchmarking}

Benchmarking is a business concept used in the field of strategic planning, marketing, restructuring, financial management and the practice of "learning from the best". There is a significant number of interpretations of benchmarking. A classical one is the definition of the founder of this management improvement method, head of the Global Benchmarking Network, Robert Kemp, who understands benchmarking as "a search for and implementation of the best practices that improve performance" (Camp, 1989). According to Hyatt (2001), benchmarking is the process of identifying the most sophisticated 
practices of other organizations and the borrowing of knowledge to create competitive advantages. Yasin (2002) defines benchmarking as a technique that can be used to identify strategic gaps and find the best strategies that eliminate such gaps. The work by Marković et. al. (2011) provides more details on benchmarking objects, which is a continuous process of identifying, understanding and adapting products, services, technologies and processes of the most successful companies in order to improve one's own business. From the point of view of management, the essence of benchmarking is described by Jetmarová (2011) who notes that it is an instrument for achieving goals through the study of the best practices and understanding of the process through which they were realized. Askarany (2014) considers benchmarking to be a practice and process at the same time, the implementation and dissemination of which is influenced by the characteristics of innovation. According to Bublyk (2009), the main essence and purpose of benchmarking is identification of differences from the compared reference bank (benchmark), determination of the causes of these differences and identification of opportunities for improving the objects of benchmarking. Moriarty and Smallman (2009) explore the theory of benchmarking, thoroughly analyzing the definition of benchmarking from different positions with the focus on its purposefulness.

Definition of benchmarking is focused on the following key areas: measurement through comparison, identification of the best practices, implementation, continuous improvement and systematic benchmarking (Camp, 1989; Hyatt, 2001; Anand \& Kodali, 2008; Moriarty \& Smallman, 2009; AlTarawneh, 2014; Alosani et al., 2016).

Benchmarking is considered as a direction of development of the strategic management concept (Yasin, 2002), competitiveness (Bublyk, 2009), a program for enhancing key business performance indicators (Moriarty \& Smallman, 2009), an instrument of management of business processes (Kryvoruchko \& Sukach, 2012), a mechanism for improving organizational efficiency (Alosani et. al., 2016), a method for comparing the effectiveness of management of small and medium-sized enterprises (Ladzani, 2016), a method for assess- ing and comparing the situation on the venture capital market (Rajchlová \& Svatošová, 2016).

Analytical review and generalization of scientific literary sources (Camp, 1989; Hyatt, 2001; Yasin, 2002; Anand \& Kodali, 2008; Moriarty \& Smallman, 2009; Bublyk, 2009; Marković et al., 2011; Jetmarová, 2011; Kryvoruchko \& Sukach, 2012; Al-Tarawneh, 2014; Alosani et al., 2016; Ladzani, 2016) revealed the existence of theoretical positions and practical experience in applying benchmarking to various economic agents. At the same time, the main attention is paid to the classification and characterization of certain types of benchmarking, the technique of its realization, the principles of organization and the use of its results in practice.

However, the issue of use of benchmarking in banks has not been widely developed and concerns mainly the formation of the quality and competitiveness of banking services (Soteriou \& Zenios, 1999), justification for the need to improve business processes (Kloba, 2009), analysis of efficiency and effectiveness (Memić, 2013; Chandrasekaran \& Madhana Gopal, 2013), the study of the most influential factors of net interest margin in different regions (Boutin-Dufresne et al., 2013), ensuring the financial security of banks (Tysyachna et al., 2015). At the same time, there is practically no methodical basis for conducting banking benchmarking; insufficiently investigated remain the issues of using benchmarking as a technology of financial management of banks, which makes it possible to increase the efficiency of implementation of such functions as planning, analysis and control. Also, insufficiently defined is the procedure for identifying a reference bank for comparison, which is important from the point of view of adapting its experience by the recipient bank due to the possible fundamental differences in their functioning.

As regards the stages of benchmarking, it is necessary to note different levels of their specification. Camp (1989) distinguishes: the planning stage (identification of the subject of benchmarking, identification of comparable organizations, determination of the method of data collection and their direct collection); the stage of analysis (definition of "gaps" in performance, prediction of 
the future performance levels); the stage of integration (discussing the results of benchmarking, setting functional goals); the stage of action (development of the plan of action, implementation of measures and monitoring of results, review of the objects of comparison); the stage of maturity (achievement of leadership positions and full integration of the best practices). Jetmarová (2011) presents a slightly different sequence of benchmarking: the planning phase (determination of the subject of benchmarking, depth of research, goal setting); the phase of data collection (the collection of internal and external data, the search of a partner for benchmarking, establishing contact for further cooperation, obtaining detailed data from the benchmarking partner, obtaining the data on the benchmarking partner from other sources); the analysis phase (transformation of data into information, sorting, monitoring of information, exclusion of irregular information, identification of differences between the organization's functioning and the best practices, classification of the causes of differences, identification of processes that require improvement, formulation of new goals, definition of the plan of changes); the phase of adaptation (development of a plan, implementation of the best practices, the connection of the new plan with the current one). In aggregated form, the benchmarking procedure is provided by Marković et al. (2011), which consists of the preparatory phase (deciding what will be measured and based on what criteria); the phase of benchmarking (data collection, measurement of results, evaluation of gaps); post-benchmarking phase (obtaining results, developing a plan of action, developing a strategy), the phase of the process of reproduction (feedback as the basis for future decisions). Kryvoruchko and Sukach (2012) offer the following sequence of benchmarking: the choice of the subject of benchmarking, internal research, the choice of reference organization, collection of external information, analysis and identification of opportunities for improvement, introduction of new ideas and proposals.

Generalization of the existing approaches made it possible to form a general list of stages of implementation of banking benchmarking: the selection of processes and objects for comparison; substantiation of the composition of indicators for evaluation; selection of the reference bank; calcu- lation and analysis of indicators of the recipient bank and the reference bank; determining the recommended values of indicators for the recipient bank; determining the directions for improving the functioning of the recipient bank and adapting the best results to the conditions of the bank's operations.

\subsection{Life cycle concept}

The concept of a life cycle, which appeared in the middle of the XX century, combines the idea of heredity, development, adaptation, survival at the level of individuals, organisms and their populations. Subsequently, analogies with living organisms began to be used in economics to study the processes of life of economic entities. According to the concept of a life cycle, the development of an economic entity can be described from the point of view of the stages of its life cycle, which are associated with causal relationships with the portfolio of strategies, structures, problems that it faces during its functioning. At each stage of a lifecycle, an economic entity has a certain configuration of characteristics that are similar at one and the same stage of the life cycle and different at others. Rahimi and Fallah (2015) indicate the influence of the life cycle on the company's parameters, stressing that ignoring the organizational scheme of life cycle by managers is one of the problems that hinder the implementation of the relevant strategy.

Today, the theory of a lifecycle continues to be within the scientific interests of researchers, expanding the scope of its application. A thorough theoretical generalization and systematization of the company's life cycle models is presented in the work of Ionescu and Negrusa (2007) who distinguish resource models, crisis models, models of inertia and decline, and also indicate that management emphasizes different goals during different phases of the companies' life cycle: in the beginning of their functioning, they are oriented towards production, during the second stage, marketing goals prevail, and during the third stage - financial goals. From this, it follows that, since benchmarking is aimed at identifying and borrowing the best practices, they must be different for each stage of the life cycle, since the goals of functioning of economic entities differ. 
Auzair (2010) also considers the theory of life cycle from the point of view of management and notes that the system of management needs changes in the process of going through the stages of life cycle to ensure that the system meets a variety of its needs. Gao and Alas (2010) demonstrate the relation between the stages of life cycle and the types of crises that may arise in the activity of enterprises that have significant potential for the use in crisis management. In the context of risk and uncertainty, Kuzmin (2017) explores the use of the concept of life cycle emphasizing its importance for solving the tasks of management. Gurianova et al. (2014) analyze the stages of the organization's life cycle through the lens of transaction costs; Jaafar and Halim (2016) indicate that the theory of life cycle is considered from the point of view of changing the value of the company, while Nordström et al. (2012) study organizational efficiency and its dependence on a certain stage of the life cycle.

The abovementioned gives grounds for concluding that the stages of life cycle affect the goals, strategies, financial and non-financial parameters, the effectiveness of economic agents, and, therefore, should be taken into account when choosing a reference organization in the process of benchmarking.

\subsection{DEA approach}

The basis of DEA is a method of linear programming, which makes it possible to find the optimal solution among the set of permissible ones. Charnes, Cooper, and Rhodes (1978), who were the first to use this method in practice and gave it the name DEA, note that the solution of the problem is reduced to the construction of an "efficient frontier" in the multidimensional environment of characteristic parameters of analyzed objects and determination of the relative efficiency of these objects.

The DEA method has become widespread in various areas of the economy to measure efficiency, productivity, performance at the level of both individual actors, regions and countries. Thus, Emrouznejad and Thanassoulis (2010) offered a dynamic index of productivity of 17 in- dustrialized countries based on the DEA method; Khodabakhshi and Aryavash (2014) use it to measure the productivity of forest districts. Shewell and Migiro (2016) highlighted the advantages of the DEA method for assessing the effectiveness of business units and presented the results of a literature review regarding its use for assessing information technologies and the system of management of supply chains. This method is also used to determine the production efficiency of automobile transport in the regional context (Grigoriev, 2010), to evaluate the efficiency of crop production (Dolgikh, 2015). One should emphasize the popularity of the DEA method in banking practice for analyzing and evaluating the efficiency, productivity and effectiveness of bank branches (Porembski et al., 2005; Wu et al., 2006; McEachern \& Paradi, 2007; Gaganis et al., 2009; Paradi et al., 2010), analyzing operational activities of banks (Lin et al., 2009), measurement of banking performance and its comparison in the private and public banking sector (Miencha et al., 2015), measurement of the cost, revenue and profit efficiency (Kocisova, 2014).

According to the DEA method it is possible to calculate the efficiency in two ways: output orientation (maximization of output variables) or input orientation (minimization of input variables). We carried out generalization of DEA models and found out that most of them use an input focused model (Camanho, 2008; Gaganis et al., 2009; Lin et al., 2009; McEachern \& Paradi, 2007; Paradi et al., 2010; Porembski et al., 2005; Sherman, 2006; Wu et al., 2006) This model will be used when selecting a reference bank for benchmarking comparison.

\section{RESEARCH METHODOLOGY}

This study is based on using the DEA method to determine the most efficient bank as a reference bank in benchmarking comparison; canonical analysis - for the formation of a list of indicators of bank performance; cluster analysis - to substantiate the levels of deviations of the actual values of comparable indicators from the target ones.

The proposed technology of banking benchmarking consists of the following stages (Fig. 1): 
Stage 1 - selection of processes and objects for comparison. Such object is the effectiveness of management of finances, customer base, business processes and personnel of the bank.

Stage 2 - substantiation of the composition of indicators for evaluation. Taking into account the views of $\mathrm{Wu}$, (2012), Ombuna et al. (2013), Ozturk \& Coskun (2014), such indicators are the indicators of the Balanced Scorecard Subsystems (BSC) "Finance", "Customers", "Business Processes", "Personnel development". Since the number of indicators is quite significant, which complicates benchmarking comparison and further development of financial decisions, the BSC subsystems distinguish the indicators with the strongest interconnections according to the approach proposed by Chmutova et al. (2017).

Stage 3 - the choice of the reference bank. In order to compare the values of indicators according to the BSC subsystems, it is necessary to choose a bank that operates effectively on the banking market. The choice of the reference bank is proposed to be carried out in a two-level procedure:

- at the first level, the list of potential objects for comparison contains only those banks that at the current moment are at the same stage of their life cycle as recipient banks. The life cycle stage is determined on the basis of the empirical model built by Vasylieva and Chmutova (2015);

- at the second level, the rating of the selected banks is carried out according to the value of the efficiency indicator $(\theta)$ calculated by the DEA method.

Regarding the type of the DEA model (CCR or BCC), Chmutova and Afanasenko (2011) justified the feasibility of using the CCR model in the ranking of banks, which looks as follows:

$\min _{\theta, \lambda} \theta$,
with restrictions: $\quad\left\{\begin{array}{l}\theta x_{0}-X \lambda \geq 0, \\ Y \lambda \geq y_{0} \\ \lambda \geq 0,\end{array}\right.$

where $\theta$ - efficiency indicator; $X$ - vector of input variables; $Y$ - vector of output variables; $\lambda$ - vector of constants, which are weight values; $x_{i}$ - vector of input variables of the $i$-th object; $y_{i}$ - vector of output variables of the $i$-th object.

Efficiency is high if $\theta$ is 1 and low if $\theta<1$.

During the next step, it is necessary to select inx put and output parameters of the model. Taking into account the existence of two main approaches to the selection of parameters - the intermediary and production ones, as well as the scope of these approaches (the first is used mainly for the comprehensive assessment of banks, and the second - for the assessment of their branches and departments), for this study we have chosen the intermediary approach. It considers banks as financial intermediaries, which accumulate the borrowed funds of customers and lend them to others at a profit. All accumulated funds and associated costs serve as input variables, while the funds provided to customers are output variables (see Figure 1).

Stage 4 - calculation and analysis of indicators with the closest connections between BSC subsystems "Finance", "Customers", "Business processes", "Development of personnel" of the reference bank and the recipient bank.

Stage 5 - setting the levels of recommended values for the recipient bank. Given the high level of comparability of the recipient bank and the reference bank (due to the selection of the latter from the list of banks at the same stage of life cycle as the recipient bank), the values of indicators achieved by the reference bank are to be used by the investigated bank as reference points in the planning of activities.

Stage 6 - determining the directions for improving the functioning of the recipient bank taking into account the chosen development strategy, goals and available resources, as well as the adaptation of the best results found to the conditions of the bank's activities. The implementation of this phase involves identification of deviations in the values of the comparable indicators, determination of the causes of such deviations and development of proposals for their elimination. It is important to determine the significance of deviations of the 


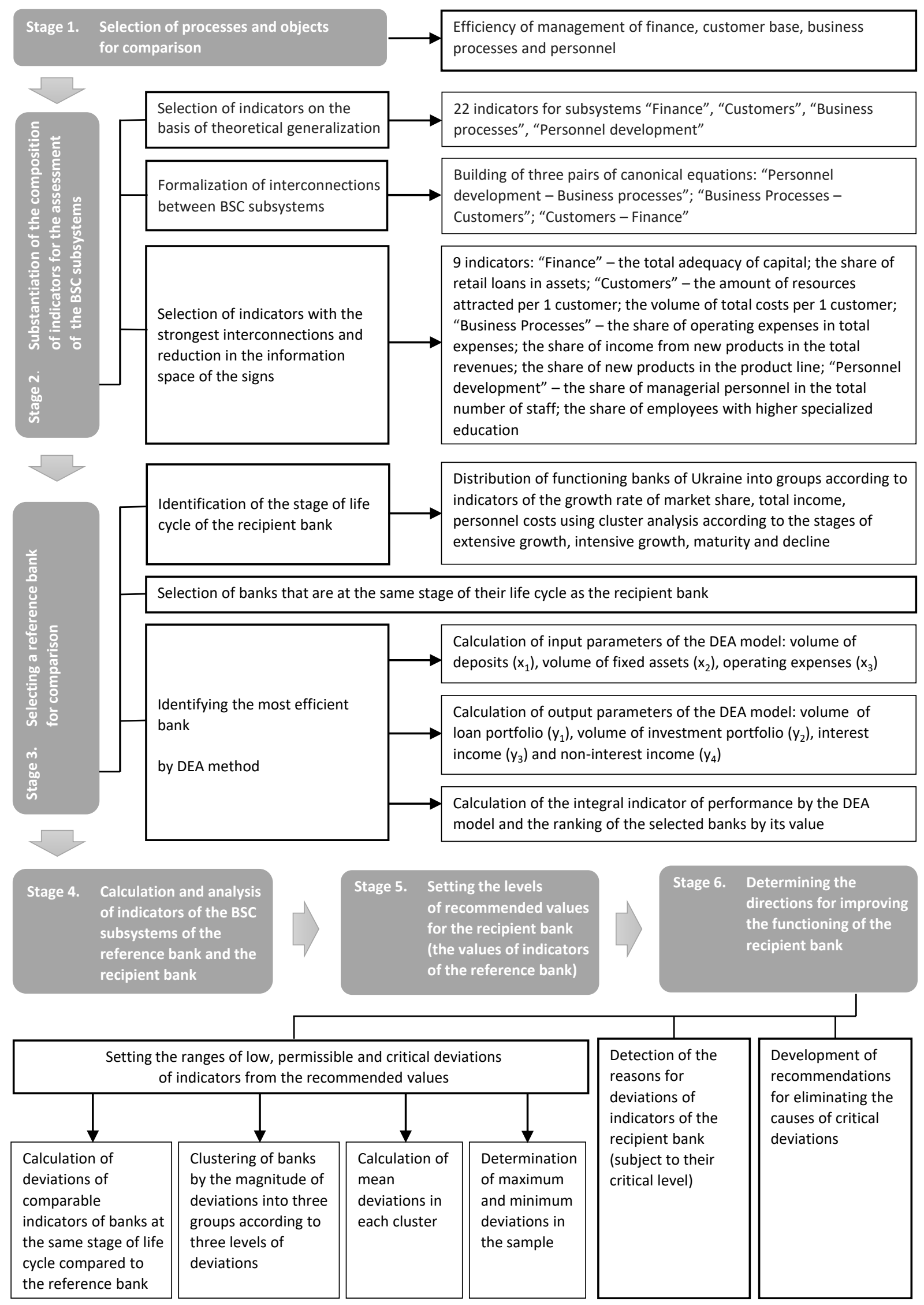

Figure 1. The sequence and content of the stages of benchmarking relating to the performance of banks 
actual values of indicators from the planned ones as the directions of response are planned depending on their values. If the value of deviations does not reach critical levels, active measures should not be used; in the opposite case, one carries out the search and implementation of reserves for ensuring the planned values of parameters and normalization of the analyzed areas of activity. Based on this, it is necessary to set the limits of low, permissible and critical deviations of indicators that reflect the effectiveness of management of finances, customer base, business processes and bank personnel. To do this the following procedure is offered:

1) identification of deviations of the values of comparable indicators of banks at one and the same stage of their life cycle from the reference bank selected at stage 3 ;

2) clusterization of banks based on the magnitude of deviations through the method of $\mathrm{k}$ means (since it is necessary to obtain three clusters according to three levels of deviations, that is, the number of clusters is known in advance);

3) calculation of the average values of deviations in each cluster;

4) setting the ranges of low, permissible and critical deviations of indicators taking into account average values in the clusters, economic content of the indicators, their normative or recommended values in the banking practice, as well as maximum and minimum deviations in the sample.

Based on the established ranges of deviations of comparable indicators, the degree of achievement of the goals set by the recipient bank is determined, the causes of critical deviations are identified, recommendations for their elimination are offered.

\section{EMPIRICAL RESULTS}

The proposed technique of benchmarking is tested on the example of Ukrainian banks, whose stage in 2016 was identified as "intense growth" on the basis of the approach developed by Vasylieva and Chmutova (2015). The calculated values of the per- formance indicator according to the DEA model and bank rankings for this indicator are presented in Table. 1. The calculations were carried out in the Microsoft Excel program in the "solution search" module.

Table 1. Performance indicators and the ranking of banks at the stage of intense growth

\begin{tabular}{|c|c|c|}
\hline Bank & $\begin{array}{l}\text { Performance } \\
\text { indicator }(\theta)\end{array}$ & Ranking \\
\hline CREDITWESTBANK PJSC & 1 & 1 \\
\hline PROMINVESTBANK PJSC & 1 & 1 \\
\hline SBERBANK PJSC & 1 & 1 \\
\hline FINANCIAL INITIATIVE CB PJSC & 1 & 1 \\
\hline CREDIT AGRICOLE BANK PJSC & 1 & 1 \\
\hline KREDOBANK PJSC & 1 & 1 \\
\hline BANK VOSTOK PJSC & 1 & 1 \\
\hline BM BANK JSC & 1 & 1 \\
\hline CREDIT EUROPE BANK PJSC & 1 & 1 \\
\hline $\begin{array}{l}\text { INTERNATIONAL INVESTMENT } \\
\text { BANK PJSC }\end{array}$ & 1 & 1 \\
\hline TRUST-CAPITAL PJSC JSB & 1 & 1 \\
\hline $\begin{array}{l}\text { UKRAINIAN CONSTRUCTION } \\
\text { INVESTMENT BANK JSC }\end{array}$ & 1 & 1 \\
\hline CONCORD PJSC JSCB & 1 & 1 \\
\hline CB CENTER PJSC & 1 & 1 \\
\hline FORTUNA-BANK JSC & 0.99 & 2 \\
\hline MOTOR BANK PJSC & 0.94 & 3 \\
\hline $\begin{array}{l}\text { BANK FOR INVESTMENT } \\
\text { AND SAVINGS }\end{array}$ & 0.87 & 4 \\
\hline BANK SICH PJSC & 0.85 & 5 \\
\hline RADABANK PJSC JSCB & 0.85 & 5 \\
\hline UKRSOTSBANK PJSC & 0.84 & 6 \\
\hline COMINVESTBANK PJSC & 0.84 & 6 \\
\hline OKCI BANK PJSC & 0.84 & 6 \\
\hline FINBANK PJSC & 0.75 & 7 \\
\hline PROCREDIT BANK JSC & 0.72 & 8 \\
\hline DIAMANTBANK PJSC & 0.71 & 9 \\
\hline ARKADA PJSC JSCB & 0.71 & 9 \\
\hline BANK GRANT PJSC & 0.49 & 10 \\
\hline
\end{tabular}

In the study, BANK GRANT PJSC was chosen as a recipient bank, because the level of its performance is insufficient (the efficiency indicator is less than one and equals 0,49). CREDITWESTBANK PJSC is the reference bank because it has a high efficiency level (equals 1) and according to its activities is comparable with the recipient bank.

The compared indicators for the BSC subsystems "Finance", "Customers", "Business processes", "Personnel development" of the reference bank and the recipient bank, as well as their deviations, are 
Table 2. Comparable indicators of the reference bank and the recipient bank

\begin{tabular}{|c|c|c|c|}
\hline \multirow{2}{*}{ BSC indicators } & \multicolumn{2}{|c|}{ Values of indicators } & \multirow{2}{*}{$\begin{array}{c}\text { Deviations of indicators } \\
\text { of the recipient bank } \\
\text { from the values of the } \\
\text { reference bank }\end{array}$} \\
\hline & $\underset{\text { (reference bank) }}{\text { CREDITWESTBANK PJSC }}$ & $\begin{array}{l}\text { BANK GRANT PJSC } \\
\text { (recipient bank) }\end{array}$ & \\
\hline \multicolumn{4}{|c|}{ Subsystem "Finance" } \\
\hline General adequacy of capital & 37.600 & 21.200 & -16.400 \\
\hline $\begin{array}{l}\text { The share of retail loans } \\
\text { in assets, } \%\end{array}$ & 0.1 & 8.4 & 8.3 \\
\hline \multicolumn{4}{|l|}{ Subsystem "Customers" } \\
\hline $\begin{array}{l}\text { The volume of general expenses } \\
\text { per } 1 \text { customer, thousand UAH }\end{array}$ & 4.910 & 7.502 & 2.592 \\
\hline $\begin{array}{l}\text { The volume of attracted } \\
\text { resources per } 1 \text { per } 1 \text { customer, } \\
\text { thousand UAH }\end{array}$ & 47.390 & 42.409 & -4.981 \\
\hline \multicolumn{4}{|c|}{ Subsystem "Business processes" } \\
\hline $\begin{array}{l}\text { The share of operating expenses } \\
\text { in total costs, } \%\end{array}$ & 88.396 & 81.590 & -6.806 \\
\hline $\begin{array}{l}\text { The share of new products in the } \\
\text { product line, } \%\end{array}$ & 26.550 & 16.670 & -9.880 \\
\hline $\begin{array}{l}\text { The share of income from new } \\
\text { products in total revenue, } \%\end{array}$ & 31.190 & 5.100 & -26.090 \\
\hline \multicolumn{4}{|c|}{ Subsystem "Personnel development" } \\
\hline $\begin{array}{l}\text { The share of managerial staff in } \\
\text { the total number of personnel, \% }\end{array}$ & 0.400 & 0.230 & -0.170 \\
\hline $\begin{array}{l}\text { The share of employees with } \\
\text { higher specialized education in } \\
\text { the total number of personnel, \% }\end{array}$ & 90.460 & 70.910 & -19.550 \\
\hline
\end{tabular}

given in Table. 2. In order to establish whether certain deviations are critical for the recipient bank and, therefore, to specify the measures to improve its efficiency, we have calculated the ranges of deviations of comparable indicators of 27 Ukrainian banks (which were at the stage of intensive growth) from the reference values.

The procedure is carried out according to the sixth stage of the benchmarking technology described above. The cluster analysis is conducted in the package Statistica 8.0 for each of the nine comparable indicators with prior standardization of their values. The quality of clusterization and the mean values of deviations in each cluster are illustrated by the data in Table. 3

Based on the calculation of mean values in the clusters, taking into account maximum and minimum deviations in the sample, economic content of the indicators, we have established the ranges of deviations of the compared indicators and their levels for the recipient bank BANK GRANT PJSC (Table 4).

In general, deviations of the comparable indicators of BANK GRANT PJSC are characterized by low and acceptable levels, which do not require immediate changes in the bank's activities. The indicator of the share of new products in total revenues has a critical deviation. Therefore, it is necessary to analyze the period of introduction of new products or services on the market, as they may not immediately bring the desired levels of income. It is also necessary to provide analytical support for the implementation of financial innovations by calculating their expected efficiency and to control the profitability of new banking products through the matching of incomes and expenses and identifying those types that are not profitable in the current and prospective periods, as well as determining the reasons for profit losses. 
Table 3. Characteristics of clusterization and mean values of deviations of comparable indicators from the reference values (for banks at the stage of intensive growth)

\begin{tabular}{|c|c|c|c|c|c|c|c|c|c|}
\hline \multirow[b]{2}{*}{ Indicator } & \multirow{2}{*}{ 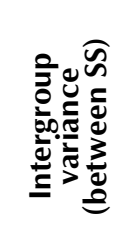 } & \multirow{2}{*}{ 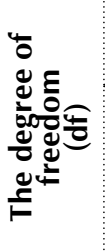 } & \multirow{2}{*}{ 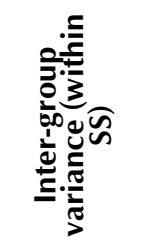 } & \multirow{2}{*}{ 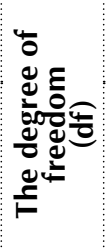 } & \multirow{2}{*}{ 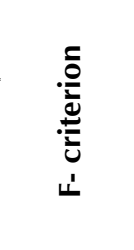 } & \multirow{2}{*}{ 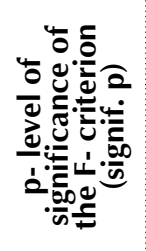 } & \multicolumn{3}{|c|}{$\begin{array}{l}\text { Average deviation } \\
\text { in the cluster }\end{array}$} \\
\hline & & & & & & & 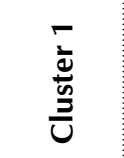 & $\begin{array}{l}N \\
\frac{ \pm}{\Delta} \\
\frac{n}{U}\end{array}$ & $\begin{array}{l}n \\
\frac{1}{ \pm} \\
\frac{n}{U}\end{array}$ \\
\hline General adequacy of capital & 222.5121 & 2 & 35.63642 & 36 & 112.3911 & 0.000000 & -20.734 & -19.180 & 18.830 \\
\hline $\begin{array}{l}\text { The share of retail loans } \\
\text { in assets }\end{array}$ & 34.04647 & 2 & 3.953533 & 36 & 155.0098 & 0.000000 & 51.145 & 27.641 & 3.555 \\
\hline $\begin{array}{l}\text { The volume of general } \\
\text { expenses per } 1 \text { customer }\end{array}$ & 33.06992 & 2 & 4.930084 & 36 & 120.7400 & 0.000000 & 9.693 & 1.020 & -0.913 \\
\hline $\begin{array}{l}\text { The volume of attracted } \\
\text { resources per } 1 \text { per } 1 \\
\text { customer }\end{array}$ & 31.21059 & 2 & 6.789408 & 36 & 82.74516 & 0.000000 & -29.970 & -19.763 & -42.890 \\
\hline $\begin{array}{l}\text { The share of operating } \\
\text { expenses in total costs }\end{array}$ & 34.38114 & 2 & 3.618862 & 36 & 171.0097 & 0.000000 & -20.027 & -5.322 & 6.040 \\
\hline $\begin{array}{l}\text { The share of new products } \\
\text { in the product line }\end{array}$ & 32.42335 & 2 & 5.576653 & 36 & 104.6542 & 0.000000 & -2.141 & -10.317 & -15.778 \\
\hline $\begin{array}{l}\text { The share of income from } \\
\text { new products in total } \\
\text { revenue }\end{array}$ & 33.49512 & 2 & 4.504875 & 36 & 133.8355 & 0.000000 & -16.973 & -24.971 & -7.673 \\
\hline $\begin{array}{l}\text { The share of managerial staff } \\
\text { in the total number } \\
\text { of personnel }\end{array}$ & 34.43362 & 2 & 3.566383 & 36 & 173.7909 & 0.000000 & -0.038 & -0.150 & -0.222 \\
\hline $\begin{array}{l}\text { The share of employees with } \\
\text { higher specialized education } \\
\text { in the total number of } \\
\text { personnel }\end{array}$ & 29.65742 & 2 & 8.342583 & 36 & 63.98900 & 0.000000 & -29.973 & -17.714 & -8.483 \\
\hline
\end{tabular}

Table 4. Ranges of deviations of comparable indicators and their levels for BANK GRANT PJSC

\begin{tabular}{|c|c|c|c|c|c|}
\hline \multirow{2}{*}{ Indicators } & \multicolumn{3}{|c|}{ Ranges of deviation } & \multicolumn{2}{|c|}{$\begin{array}{c}\text { Deviations of BANK GRANT } \\
\text { PJSC }\end{array}$} \\
\hline & Low level & $\begin{array}{c}\text { Acceptable } \\
\text { level }\end{array}$ & Critical level & Value & Level \\
\hline \multicolumn{6}{|c|}{ Subsystem "Finance" } \\
\hline General adequacy of capital & {$[0 ;-19.18]$} & $\begin{array}{l}(-19.18 \\
-27.00]\end{array}$ & $\begin{array}{l}(-27.00 \\
-29.77]\end{array}$ & -16.400 & Low \\
\hline The share of retail loans in assets, $\%$ & {$[0 ; 27.64]$} & $(27.64 ; 51.15]$ & $(51.15 ; 62.09]$ & 8.3 & Low \\
\hline \multicolumn{6}{|c|}{ Subsystem “Customers" } \\
\hline $\begin{array}{l}\text { The volume of general expenses } \\
\text { per } 1 \text { customer, thousand UAH }\end{array}$ & {$[0 ; 1.02]$} & $(1.02 ; 9.69]$ & $(9.69 ; 11.83]$ & 2.592 & Acceptable \\
\hline $\begin{array}{l}\text { The volume of attracted resources } \\
\text { per } 1 \text { per } 1 \text { customer, thousand UAH }\end{array}$ & $\begin{array}{l}{[-4.98 ;} \\
-19.76]\end{array}$ & $\begin{array}{l}(-19.76 \\
-29.97]\end{array}$ & $\begin{array}{l}(-29.97 \\
-46.56]\end{array}$ & -4.981 & Low \\
\hline \multicolumn{6}{|c|}{ Subsystem "Business processes" } \\
\hline $\begin{array}{l}\text { The share of operating expenses } \\
\text { in total costs, } \%\end{array}$ & {$[0 ;-5.32]$} & $\begin{array}{c}(-5.32 ; \\
-20.03]\end{array}$ & $\begin{array}{l}(-20.03 ; \\
-26.02]\end{array}$ & -6.806 & Acceptable \\
\hline $\begin{array}{l}\text { The share of new products } \\
\text { in the product line, } \%\end{array}$ & {$[0 ;-10.32]$} & $\begin{array}{l}(-10.32 ; \\
-15.78]\end{array}$ & $\begin{array}{l}(-15.78 ; \\
-19.14]\end{array}$ & -9.880 & Low \\
\hline $\begin{array}{l}\text { The share of income from new } \\
\text { products in total revenue, } \%\end{array}$ & {$[0 ;-7.67]$} & $(-7.67 ;-16.97]$ & $\begin{array}{l}(-16.97 \\
-30.44]\end{array}$ & -26.090 & Critical \\
\hline \multicolumn{6}{|c|}{ Subsystem "Personnel development" } \\
\hline $\begin{array}{l}\text { The share of managerial staff } \\
\text { in the total number of personnel, } \%\end{array}$ & {$[0 ;-0.15]$} & $(-0.15 ;-0.22]$ & $(-0.22 ;-0.27]$ & -0.170 & Acceptable \\
\hline $\begin{array}{l}\text { The share of employees with higher } \\
\text { specialized education in the total } \\
\text { number of personnel, } \%\end{array}$ & {$[0 ;-17.71]$} & $\begin{array}{l}(-17.71 ; \\
-29.97 j\end{array}$ & $\begin{array}{l}(-29.97 \\
-39.94]\end{array}$ & -19.550 & Acceptable \\
\hline
\end{tabular}




\section{CONCLUSION}

Benchmarking is an effective technique for managing the bank's finances, which makes it possible to identify the strengths and weaknesses of its functioning, to constantly monitor and implement the best practices, to use the revealed patterns in the implementation of the functions of financial management.

The assessment of bank performance is based on the BSC method while the selection of indicators for benchmarking comparisons is based on the identification of causal relationships between the subsystems "Finance", "Customers", "Business processes", "Personnel development" that emerge on each stage of the bank's life cycle reflecting its target characteristics. It makes it possible to determine the directions and order of realization of the bank's objectives and to form mechanisms for their achievement.

The developed procedure for bank benchmarking involves a two-stage process of selecting a benchmark reference bank for comparison: 1) selection of banks that at the current moment are at the same stage of their life cycle as the recipient bank; 2) ranking of the selected banks according to the value of indicator of integral efficiency calculated with the DEA method and identification of the most efficient bank.

The technique of benchmarking is also supplemented by the determination of the boundaries of low, permissible and critical deviations of the actual values of comparable indicators of the management of finances, customer base, business processes and bank personnel from the recommended ones. This is implemented in the following sequence: 1) identification of deviations of the values of comparable indicators of banks at one and the same stage of their life cycle from the reference bank; 2) clusterization of banks based on the magnitude of deviations according to three levels of deviations (low, permissible and critical); 3) calculation of average deviations in each cluster; 4) setting the ranges of deviations taking into account average values in the clusters, economic content of the indicators, their normative or recommended values in the banking practice, as well as maximum and minimum deviations in the sample.

\section{REFERENCES}

1. Alosani, M. S., Al-Dhaafri, H. S., Bin Yusoff, R. Z. (2016) Mechanism of Benchmarking and Its Impact on Organizational Performance. International Journal of Business and Management, 11(10), 172-183. http://dx.doi. org/10.5539/ijbm.v11n10p172

2. Al-Tarawneh, H. (2014). The Utilization of Benchmarking in the Jordanian Banking Sector. Journal of Management Research, 6(3), 49-57. https://doi. org/10.5296/jmr.v6i3.5299

3. Anand, G., Kodali, R. (2008). Benchmarking the benchmarking models. Benchmarking: An International Journal, 15(3), 257-291. https://doi. org/10.1108/14635770810876593

4. Askarany, D. (2014). Characteristics of innovation and the diffusion of benchmarking.
Problems and Perspectives in Management, 12(4-2), 563-572. Retrieved from https://businessperspectives.org/media/zoo/applications/publishing/templates/ article/assets/js/pdfjs/web/viewer. php?file=/pdfproxy.php?item_ id:6175

5. Auzair, S. Md. (2010). Organisational Life Cycle Stages and Management Control Systems in Service Organisations. International Journal of Business and Management, 5(11), 56-65. http://dx.doi.org/10.5539/ijbm. v5n11p56

6. Boutin-Dufresne, F., Williams, O., Peña, S., Zawisza, T. A. (2013). Benchmarking Banking Sector Efficiency Across Regional Blocks in Sub-Saharan Africa: What Room for Policy? IMF Working Paper No. 13/51. International Monetary
Fund, 28 p. Retrieved from http:// www.imf.org/external/pubs/cat/ longres.aspx?sk=40344 (referred on $11 / 04 / 2017$ )

7. Bublyk, M. I., Khimiak, M. M., Liber, M. V. (2009). Benchmarkinh yak sposib oderzhannia konkurentnykh perevah. Naukovyi visnyk NLTU Ukrainy, 19(5), 136-139.

8. Camanho, A. S., Dyson, R. G. (2008). A generalisation of the Farrell cost efficiency measure applicable to non-fully competitive settings. International Journal of Management Science, 36, 147-162. https://doi.org/10.1016/j. omega.2005.12.004

9. Camp, R. C. (1989). Benchmarking: The Search for Industry Best Practices That Lead to Superior Performance. New York: Quality Press. 
10. Chandrasekaran, R., Madhana Gopal, R. (2013). Evaluation of Efficiency and Benchmarking Commercial Banks in India: A Combined PCA and DEA Approach. International Journal of Statistika and Mathematika, 8(2), 60-70.

11. Charnes, A., Cooper, W. W., Rhodes, E. (1978). Measuring the efficiency of decision making units. European Journal of Operational Research, 2, 427-444.

12. Chmutova, I. M., Afanasenko, M. V. (2011). Zovnishnie reitynhove upravlinnia bankom metodom DEA (Data Envelopment Analysis). Problems of Economy, 2, 75-79.

13. Chmutova, I., Vovk, V., Bezrodna, O. (2017). Analytical tools to implement integrated bank financial management technologies. Economic Annals-XXI, 163(1-2(1)), 95-99. https://doi.org/10.21003/ ea.V163-20

14. Dolgikh, Y. (2015). Otsinka efektyvnosti vyrobnytstva ta realizatsii zerna ta zernobobovykh kultur v Ukraini metodom DEA Bulletin of Sumy National Agrarian University. Series "Economics and Management”, 5(64), 126-130.

15. Emrouznejad, A., Thanassoulis, E. (2010). Measurement of productivity index with dynamic DEA. International Journal of Operational Research, 8(2), 247260. https://doi.org/10.1504/ IJOR.2010.03314

16. Gaganis, C., Liadaki, A., Doumpos, M., Zopounidis, C. (2009). Estimating and analyzing the efficiency and productivity of bank branches: Evidence from Greece, Managerial Finance, 35, 202-218. https://doi. org/10.1108/03074350910923518

17. Gao, J., Alas, R. (2010). The impact of crisis on enterprise lifecycle. Problems and Perspectives in Management, 8(2), 9-20.

18. Grigoriev, G. (2010). Problemy otsinky vyrobnychoi efektyvnosti avtomobilnoho transportu Ukrainy. Naukovi zapysky NaUKMA, 107, Ekonomichni nauky, 22-26.
19. Gurianova, E.A., Gurianov, I. N., Mechtcheriakova, S. A. (2014). The Influence of Phase the Organizational Life Cycle on Organizational Structure Management and Transaction Costs, Asian Social Science, 10(20), 137-142.

20. Hyatt, L. (2001). Benchmarking: How Does Your Organization Measure Up? Nursing Homes, 50(5), 12-14.

21. Ionescu, G., Negrusa, A. L. (2007). The Study about Organizational Life Cycle Models. Review of International Comparative Management, 8(4), 5-17.

22. Jaafar, H., Halim, H. A. (2016). Refining the Firm Life Cycle Classification Method: A Firm Value Perspective, Journal of Economics, Business and Management, 4(2), 112-119. https://doi.org/10.7763/JOEBM.2016.V4.376

23. Jetmarová, B. (2011). Comparison of Best Practice Benchmarking Models, Problems of Management in the 21st Century, 2(2), 76-84.

24. Khodabakhshi, M., Aryavash, K. (2014). The global Malmquist productivity index under the optimistic pessimistic approach of DEA. International Journal of Operations Research, 11(4), 131-137.

25. Kloba, R. L. (2009). Reinzhynirynh i benchmarkinh yak instrumenty vdoskonalennia upravlinnia bankivskoiu diialnistiu. Naukovyi visnyk NLTU Ukrainy, 19(5), 247-252.

26. Kočišová, K. (2014). Application of Data Envelopment Analysis to Measure Cost, Revenue and Profit Efficiency. Statistika, 94(3), 47-57.

27. Kryvoruchko, O. M., Sukach, Ju. O. (2012). Osnovni polozhennia benchmarkinhu biznes-protsesiv ATP. Economics of the transport complex, 20, 77-89.

28. Kuzmin, E. A. (2017). Risk and uncertainty in concept of corporate lifecycle. Problems and Perspectives in Management, 15(1), 107-114. http://dx.doi. org/10.21511/ppm.15(1).2017.11
29. Ladzani, W. (2016).

Benchmarking the South African Excellence Model against world class best practice business Excellence Models. Environmental Economics, 7(4), 8-19. http://dx.doi.org/10.21511/ ee.07(4).2016.01

30. Lin, T. T. Lee, C. C., Chiu, T. F. (2009). Application of DEA in Analyzing a Bank's Operating Performance. Expert system with application, 36(5), 88838891. https://doi.org/10.1016/j. eswa.2008.11.018

31. Marković, L., Dutina, V., Kovačević, M. (2011). Application of Benchmarking Method in the Construction Companies. Facta universitatis - series: Architecture and Civil Engineering, 9(2), 301314. https://doi.org/10.2298/FUACE1102301M

32. McEachern, D., Paradi, J. C. (2007). Intra- and Inter-Country Bank Branch Assessment Using DEA. Journal of Productivity Analysis, 27(2), 123-136. https:// doi.org/10.1007/s11123-0060029-Z

33. Memić, D., Škaljić-Memić, S. (2013). Performance Analysis and Benchmarking of Commercial Banks Operating in Bosnia and Herzegovina: a DEA Approach. Business Systems Research, 4(2), 17-37. https://doi.org/10.2478/ bsrj-2013-0010

34. Miencha, I.O., Murugesan, S., Vasanth, V., Lingaraja, K., Raja, M. (2015). Efficiency Measurement of Kenyan Commercial Banks. Mediterranean Journal of Social Sciences, 6(4), 621-631. https:// doi.org/10.5901/mjss.2015. v6n4s2p621

35. Moriarty, J. P., Smallman, C. (2009). En route to a theory of benchmarking. Benchmarking: An International Journal, 16(4), 484-503. https://doi. org/10.1108/14635770910972423

36. National Bank of Ukraine. Banking system indicators (2016) Retrieved from https://bank.gov. ua/control/uk/publish/article?art_ id=34661442\&cat_id=34798593 (accessed on 06/04/2017). 
37. Nordström, C., Choi, G. E., Llorach, C. (2012). The Organizational Life Cycle Stages and Effectiveness: A Study of Swedish Gazelle Companies. Bachelor's Thesis in Business Administration. Retrieved from https://www.diva-portal. org/smash/get/diva2:578624/ FULLTEXT01.pdf. (referred on 18/06/2017)

38. Ombuna, D.S., Omido, K., Garashi, H. M., Odera, O., Okaka, O. (2013). Impact of balanced scorecard usage on the performance of commercial banks. International Journal of Information Technology and Business Management, 10(1), 40-48.

39. Ozturk, E., Coskun, A. (2014). A Strategic Approach to Performance Management in Banks: The Balanced Scorecard. Accounting and Finance Research, 3(3), 151-158. https://doi. org/10.5430/afr.v3n3p151

40. Paradi, J. C., Rouattb, S., Zhu, H. (2010). Two-stage evaluation of bank branch efficiency using data envelopment analysis, Omega, 39(1), 99-109. https://doi. org/10.1016/j.omega.2010.04.002

41. Porembski, M., Breitenstein, K., Alpar, P. (2005). Visualizing efficiency and reference relations in data envelopment analysis with an application to the branches of a German bank. Journal of Productivity Analysis, 23(2), 203-221. https://doi.org/10.1007/s11123005-1328-5
42. Rahimi, F., Fallah, S. (2015). Study of Organizational Life Cycle and its Impact on Strategy Formulation. Procedia - Social and Behavioral Sciences, 207, 50-58. https://doi. org/10.1016/j.sbspro.2015.10.152

43. Rajchlová, I. J., \& Svatošová, I. V. (2016). Benchmarking study on the venture capital market in the Czech Republic, Hungary and the Netherlands. Investment Management and Financial Innovations, 13(3-1), 191-202. http://dx.doi.org/10.21511/ imfi.13(3-1).2016.05

44. Rigby, D., Bilodeau, B. (2015). Management Tools \& Trends 2015. Retrieved from http://www.bain. com/publications/articles/management-tools-and-trends-2015.aspx (accessed on 06/04/2017)

45. Sherman, H. D., Rupert, T. J. (2006). Do bank mergers have hidden or foregone value? Realized and unrealized operating synergies in one bank merger. European Journal of Operational Research, 168, 253-268. https://doi. org/10.1016/j.ejor.2004.05.002

46. Shewell, P., \& Migiro, S. (2016). Data envelopment analysis in performance measurement: a critical analysis of the literature. Problems and Perspectives in Management, 14(3-3), 705-713. http://dx.doi.org/10.21511/ ppm.14(3-3).2016.14

47. Soteriou, A., Zenios, S. (1999). Operations, Quality, and Profitability in the Provision of Banking Services. Management
Science, 45(9), 1221-1238.

Retrieved from http://www.jstor. org/stable/2634834 (accessed on 09/04/2017)

48. Tysyachna, Yu. S., Azizova, K. M., Rats, O. M. (2015). Kompleksna tekhnolohiia benchmarkinhu yak instrument zabezpechennia finansovoi bezpeky banku. Actual problems of economics, 5, 427-437. Retrieved from http://nbuv.gov.ua/ UJRN/ape_2015_5_53 (accessed on $11 / 04 / 2017$ )

49. Vasylieva, T. A., Chmutova, I. M. (2015). Empirical model of bank life cycle. Actual Problems of Economics, 10(172), 352-361. Retrieved from http://nbuv.gov.ua/ UJRN/ape_2015_10_45 (accessed on $11 / 04 / 2017$ )

50. Wu, D., Yang, Z., Liang, L. (2006). Efficiency analysis of cross-region bank branches using fuzzy data envelopment analysis. Applied $\mathrm{Ma}$ thematics and Computation, 181, 271-281. https://doi.org/10.1016/j. amc.2006.01.037

51. Wu, H. Y. (2012). Constructing a strategy map for banking institutions with key performance indicators of the balanced scorecard. Evaluation and Program Planning, 35(3), 303-320. https://doi.org/10.1016/j.evalprogplan.2011.11.009

52. Yasin, M. M. (2002). Theory and practice of benchmarking: then and now. Benchmarking: An International Journal, 9(3), 217-243. https://doi. org/10.1108/14635770210428992 